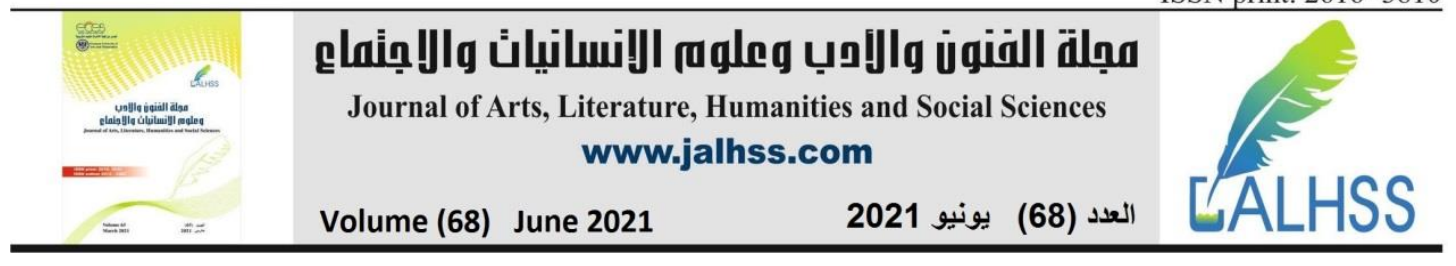

\title{
Culture and values in Kurdish society in the Kurdistan Region of Iraq
}

Prof. Dr. Rashad Miran

College of Arts, Salahaddin University- Erbil

Email: rashad.meran1 @su.edu.krd

Doc.Mgr.Katarina Slobodova Novakova

PhD. , Faculty of Arts UCM Trnava

Email: knovacka@gmail.com

Herdn Ibrahim Ahmed

Salahaddin University- Erbil

Email: herdn.ahmed@su.edu.krd

\section{ABSTRACT}

There is not a lot anthropological research on Kurdish culture, especially in terms of values; Research can hardly be found about "culture and values" subjects particularly when field research methods are used. In spite of the use of written sources, a direct and notes by researchers have been resorted within research field to achieve appropriate objectives and outcomes.

Keywords: Kurdish society, culture, value. 


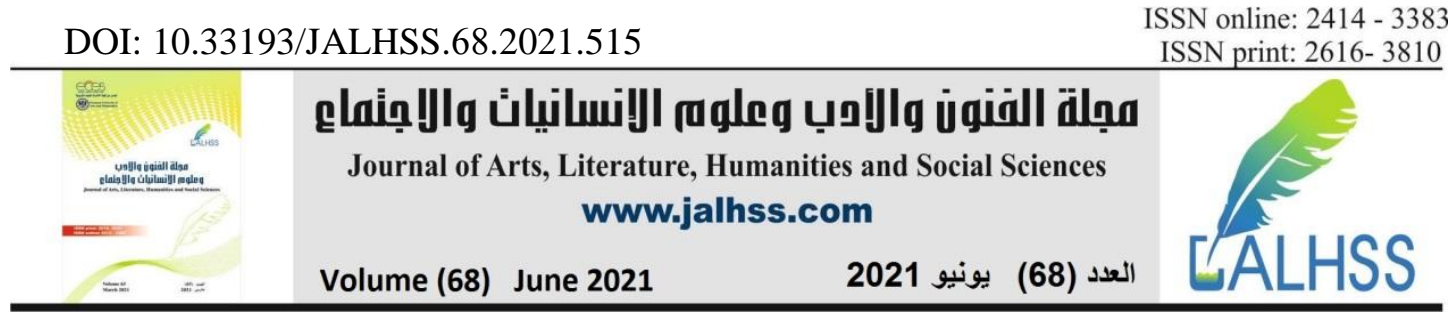

\section{Introduction}

Each society has its social system that in an organic regulation of its elements forms the conduct of life for its inhabitants. It creates the greatest and the most important and effective social phenomenon which is named "culture".

Culture is regarded as a structural phenomenon of any social system. In other words, it is impossible for a society to exist without a culture; Even every united society produces this phenomenon- because culture stands for a particular lifestyle of nation. that will be explained later.

Culture means the state of life; members of each community live in a specific way which is reflected in their beliefs, values and criteria In addition, tools and equipments are formed a method and people's lifestyle. The definition of culture is not a simple task. Thus until now hundreds of culture definitions have been recommended.

Anthropologists and sociologists constantly trace back to the famous definition defined by English anthropologist E.B.Taylor hundred years ago. Taylor (year) said that culture is "that complex whole which includes knowledge, belief, art, law, morals, custom, and any other capabilities and habits acquired by man as a member of society (Scott and Marshal 2009, 152). It is clear that Taylor's attention was nonmaterial Culture only; even in a part of his book material things for example axe, spear, bow and arrow are mentioned and they are considered as the cultural elements (AL-Khteb 2005, 21), so these cultural elements should be pointed in the definition. However there are contemporary definitions for Culture, but some of them have deficiency. For example, Culture is a network of behaviors and ideas have been taught people. These behaviors also produce material culture such as houses and musical instruments. Culture can also be defined as a complex... (Ember, Ember and Peregrine 2007, 224), is: Complex a component of behavior, attitude, and symbols that individuals use in their relationships with others on a daily basis. (Kimmel and Aronson 2008, 62).

A clearer and more comprehensive definition of culture will recommended - culture is: "All the material and spiritual achievements that have been achieved throughout the history of a society and are used to manage daily life" (Miran 2016, 215).

There are two types of cultural elements, material and immaterial: material includes: foods, clothes, shelter, equipments, music and work instruments, the weapons and jewelry. In addition, immaterial represents language, value, religion, art, literature and science tradition.

As it is clear, in every society people's lifestyle has been controlled by these cultural elements, so it is important to pay attention to these terms.

- Daily life- Any element that is not used in social life will lose its cultural characteristics. It will be regarded as heritage element and collected in ethnographic museums. 


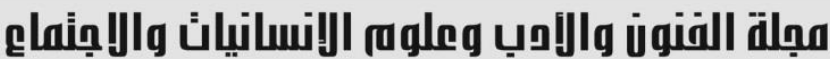 \\ Journal of Arts, Literature, Humanities and Social Sciences www.jalhss.com}

Volume (68) June 2021

العدد (68) يونيو 2021

- Achievement- All these material and nonmaterial inventions remain and perform various tasks and functions.

- History - most of these achievements, especially immaterial are historical which has been created throughout the history of the nation. For example values, customs, quote, mythical and oral literature. For this point of view, Culture is a historical-social phenomenon.

Culture is a wide subject, thus experts in various fields have their opinions about it, because there is a direct connection between culture and knowledge.

For example, a social language expert Dr. Hedson who supports Goodenouh's opinion he said: " Culture term is used in different senses but they express the features of society, especially when is concern with comparison among groups. And ... " Goodinoff continues and said, " In my opinion, the culture of any society is something that everyone must know or believe in it in order to behave in a way that be accepted by others so the culture is that people learn. As a result, culture is the knowledge. the meaning (Hadsn 1987, 130). Linguistic Canadian C.Hachman, defined the term culture as "shared knowledge" (Hachman 1989, 177); Or the shortest definition: It is the environment that man has created (Al-Jalbi 1984, 66).

All in all, culture is an important, wide and complex subject; there is no side and no social field to consider culture; this culture nature, to a large extent, has prevented to reach the general theory. But at the same time, the "cultural relativity" principle forces experts to consider any culture based on the special condition and its meaning and values (Ghidnz 2005); Perhaps the same amount has been due to the variety of theories and views on culture.

From this point of view, anthropology also has its own views, perspectives, and perspectives on culture.

\section{Anthropological view of Culture}

The analysis and view of an expert anthropologist, that is different from inexpert people; that is why these are the ones who one should take their views and an analysis into consideration:

1- Culture is not an abstract phenomenon, but is related to the phenomena and events around the area...

2- Reviewing the historical color of culture to understand the phenomena and its developments...

3- And considering the reason for the place.

4- Human behavior and attitude, some outside the relationship and social institutions (Jedins 2000, 279).

5- The elements of the culture such as language and religion, have their independency.

6- The culture is dynamic. 


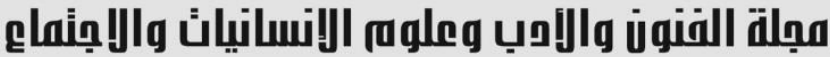 \\ Journal of Arts, Literature, Humanities and Social Sciences www.jalhss.com}

Volume (68) June 2021

العدد (68) يونيو 2021

Cultural dynamics is an ever active and stiff phenomenon. And that's a must, because it has to preserve the social system... so, if there's any chasm or disturbance in the system, culture will intervene and attempt to resolve it.

Same goes with the concept of "cultural crisis" which only emerges as the elements of ancient and modern culture come into collision; the term is coined to express the complications of the situation. Although it could be inaccurate to say that culture is in crisis, because both of the elements, ancient and modern, will never come to a halt, both of them continuously operate to perform their duties; on the contrary this intermix of elements is a necessary step towards enrichment and fulfillment of culture, that's why using such terms and concepts, in our opinion, are false and unscientific.

\section{forms of culture}

Structural of culture can be formed as follows:

1- Cultural trait; are the smallest unit of culture which is always difficult to observe, because each cultural substance constitutes of many smaller units...

2- Cultural complex; is large cluster of cultural traits.

3- Cultural circle; refers to a region in which several cultures communicate and exchange

4- Cultural pattern; is formed when traits and complexes become related to each other in functional roles. Cultural patterns survive and evolve, not smaller units (Salim 1981, 230-235).

\section{Sub culture:}

Culture is a wide and general phenomenon that reigns over all social system. Nonetheless, sometimes, phenomenon such as sub culture is emerged within it.

Within society, there are several types of groups, that all belongs to the same culture. But some of these communes, for reasons such as geography, dialect, and religion... gain certain characteristics and features that separates them remarkably from other communes, for example; a rough mountainous region (e.g. Hawraman), cities and countries on the borders or coastal towns; the difference and the characteristics of a lingual dialect (Hawramy, Zaza); religion such as Ezedi, Kakaie....

Although, ultimately, all the small cultures mentioned belong to the general culture, but because of their distinctive features, they're distinguished from the other members of society to an extent. 


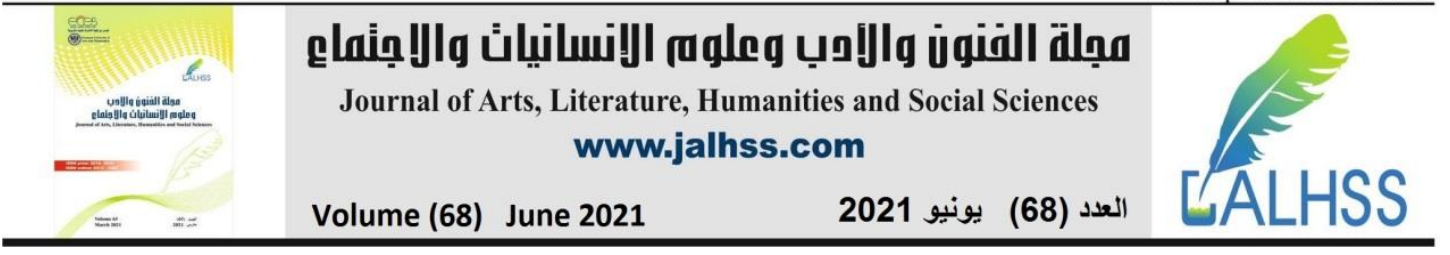

\section{Value:}

Life is full of values; social life of humans constitutes of myriad values... each act, thought and behavior of any human has many values, not only that, even every single item and stuff that humankind possess contains value - humans don't do valueless things and don't possess valueless items.

Culture, which is responsible of social life- runs and controls value. All cultural elements are full of values, and there exists criteria to the values in order to be considered properly.

From here, we can say that value creates the core of cultural elements- take each cultural element, material and spiritual, that consists of one or many values; for example: nutritional value- survival, consumption, taste and desire....; costume, self-protect, adaptation, beauty...

Lingual values- communication, expression, conveying ideas, beliefs and desires...

Religion- spiritual values (belief in spiritual values, peace of mind), cooperative social bonds...

Art- aesthetic values; literature- epic; science, development...

As for custom, it is the measure of commitment and following these values. It is clear that value exists within all the sections of culture; therefore, it'd be a correct definition to say; values are the core, meaning and importance of cultural elements...

Many definitions have been established; Howard Pecker claims that values are objects that refer to the necessities. Steward Dud- values are interests and desires (things that humans need). Neil Smelser states values are the wanted aims that direct the activities of humans. Clod Clackson- values are imagining to select a purpose and forms of allowed behaviors. Robert Park- anything capable of being appreciated. Melton Roche- value is a belief that stays and refers to an activation of a person or a society towards a goal (Al-Jalbi 1984, 130), (AlBuiumi 2002, 139-147).

It can be concluded that value is all that's mentioned above (belief, desire, requirement, purpose...) that's why we prefer the word "core" to be more general.

\section{Values and social system:}

Human's social life isn't random and unfounded; on the contrary, it's been organized for a long time in a process full of human experience in which each fundamental social aspect has its own historical and philosophical cause, that's why social norms are difficult to change. What provides such strength and rigidity is value, because any goods, tools, ideas and beliefs 


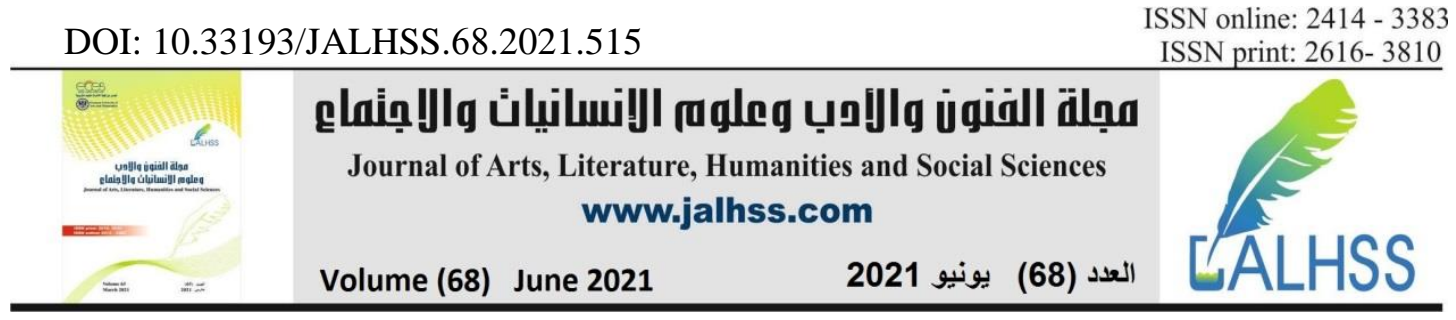

that loses its value, also loses its cultural essence and purpose, which means no one will be committed to it.

Here we can extract an idea that culture in general, refers to its own social aspects, those values that perpetuates the system.

Human history has invented myriad social systems for grouping humans; each of these groups and their members, according to historical experiences has provided a certain type of thinking in which it has given value to certain aspects of life that are differ from values of other groups. These have created a differences among social systems and that's why systems are different from each other. For example - the main values of authoritarian system is authority, tribes and hierarchy. In capitalism - profit, freedom, exploitation; in socialism - equality, cooperation, social justice. Meanwhile those differences in values become a standard of levels of development in social systems. Also such differences in values can be the cause of misunderstanding between societies, countries and nations in the world, it's non exaggeration to say that many of the world's conflicts, disputes and world wars are due to those misunderstandings.

\section{Social and cultural values of Kurdish society:}

Defining and selecting Kurdish social system is not an easy task; that's due to many historical, social, ethnicity and cultural reasons. But we can notice that Kurdish society is at a critical point, in which many aspects of ancient and modern culture have intermixed and this has created a complex and foggy situation- this is an extremely difficult and complicated subject. But has provided an interest to psychologist and anthropologists for navigating the personality of Kurds. How do Kurds think? What do they care about? Their values are behind their behaviors?

Under the scope of those historical, social and cultural conditions that are dominated in Kurdish society, some common values will be pointed out between new generation and old generation. They will be analyzed and measured their effects on social lives of Kurds.

\section{Honour:}

Honour is the pinnacle of all values held in the Kurdish society, in particular when the matter concerns behavior toward women. Humiliation, extortion and degradation of women are unwarranted in patriarchal society and violating this principle may lead to bloodshed. Preserving honour have always been of utmost importance for Kurdish people. 


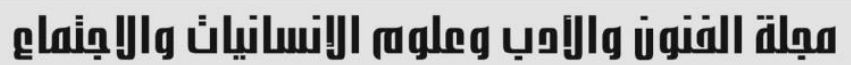

Journal of Arts, Literature, Humanities and Social Sciences

www.jalhss.com

Volume (68) June 2021

العدد (68) يونيو 2021

\section{Bravery:}

Bravery, courage and fearlessness... this is a very vital value among Kurds and still have Kurdish society under its spell; people who have this trait are looked at with respect and wonder. This value contains a resistant spirit... the spirit that Kurds always needed, sought and obtained- you can find the fingerprint of this value in Kurdish history pages.

\section{Age:}

Being old in age represents experience and knowledge; the older people get, the higher their social status become. Young people, kids and adolescence, must always be obedient to their elders - and must never raise their voices over their elders; not only that, even at family meetings the younger generation doesn't have the right to talk nor to sit in the manner they wish... this is a very important social value in such societies in which age and experience represent knowledge- in this case, intelligence, literacy and diploma doesn't play a key role... (Social position and statues also play an important role).

\section{Gender:}

Men are ideal beings in Kurdish society, all their doings are considered graceful, and every righteous act is considered as a sign of masculinity, even if the doer is female in nature - and this clearly shows the dominance of patriarchal rules in Kurdish society. Masculinity has one of the highest values among Kurdish social lives. Kurdish social system in constructed based on laws and principles of patriarchy in which the leading role and position is bestowed to men, on the other hand, female gender has been cast away, and has become a target of tease and taunt by men... it's worth noting; because this has become a value and a part of the system, even the females are obedient to such rules now. In such systems women do not reach high political, social and religious status.

\section{Religion:}

The social system has created every opportunity to produce religious individuals; and for this, large religious agencies are operated to work on the spiritual and emotional of the individuals, and the attempts have succeeded any time. Religious values are boldly manifested in every details of daily lives; for example, in speaking (god's great, god knows, god willing, god have mercy upon him). Furthermore, religious phenomenon glares in the material culture as well, 


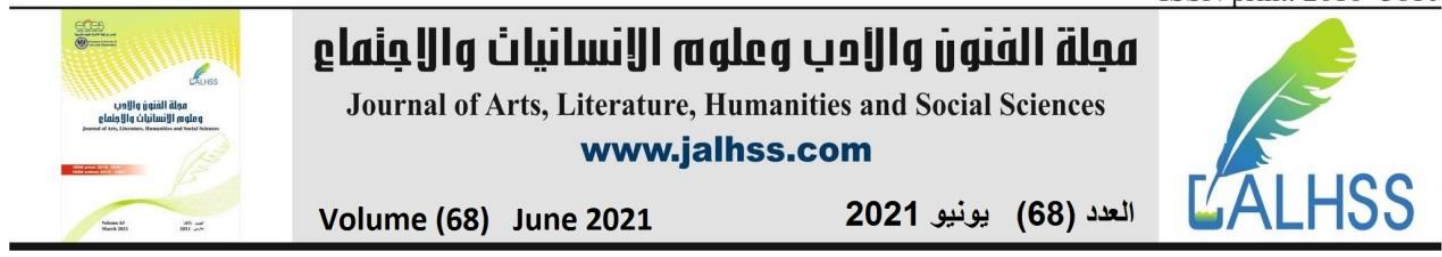

such as; mosque, clothes, beards, living a different lifestyle in Ramadan, feast and religious ceremonies...

\section{Acquaintanceship:}

Acquaintanceship is the main and most important type of relationship in the social systems, including blood relations and marriage relations. Relations control a wide area of social relationships in Kurdish lives... we're each other acquaintance, we should be of use to each other- no matter who you are, or where you work or what your capabilities are... the bond of acquaintances doesn't lose its role and importance.

\section{Being social (attending in feasts and ceremonies)}

Kurds have lost their individuality, so they must obey all the endless conditions of social domains. Participating in all the social ceremonies; burying the deceased, funeral, weddings, suiting, visiting, gatherings... If not, you're a marooned individual... because these activities, according to the large portion of society, have their values and meanings- attending ceremonies, at its core, is a manifestation of social contribution which is the fundamental aspect of social life of any society.

\section{Localism:}

This is also another negative value of our society. "people from our side" this is an expression that's being uttered by everyone and it imposes a lot of commitment. It can lead to a lot of unexpected consequences. Localism is a sign of a scattered society; which means a society that lack unison and a perfection of ethics that's necessary to rule out the differences between its elements and aspects.

\section{Love:}

Love is a humane and social value, it expresses the spiritual, moral and emotional aspect of individuals towards each other; although love has a large psychological dimension, but at the same time, it's a social and cultural value - it's the system that teaches how, how much and whom to love; and in this case, the measurement for love is obedience and compliance; 'I only love you once you obey me and follow me'!!! 


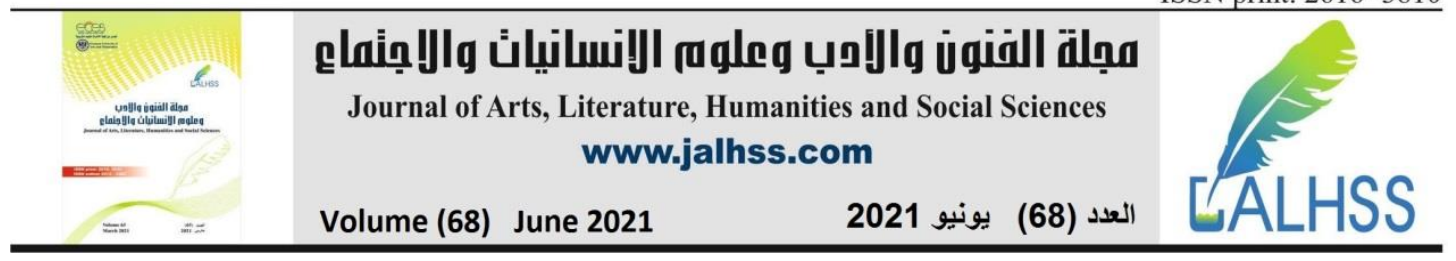

It's worth noting that in our society the reigns of love has occupied the narrowest part of our lives, which might not exceed the circle of family, even within this circle, its manifestation is dim. Apart from the affection of a mother to her children, none expresses love to the other verbally.

Up to this point, if a father hugs his children amid people, he will become a subject of mockery. Such expressions of affection are a taboo.

These are all values of olden days, but they still hold a firm place in society, in the situation for Kurdish society is in a critical point, we can notice many new, and contemporary social, political and economic values are being, more or less, instructed and followed.

Such as; democracy, diverse-policies, nations and religions, equity, human rights, animal rights, women rights

\section{Social standards:}

To ensure and observe the effectiveness of the values, culture has set up certain standards that the members of society has to obey; and the standards have to be evident and observable, and clearly reflect upon speaking, acting, and behaving of the individuals. In other words, customs which include the forms of speech, acts, and behavior of the people precisely represent the values- hence, obeying the traditions means considering and following the values. According to Anthony Giddens, the standards are the rules of behavior that represent the values of a culture.

\section{Conclusion:}

- Kurdish society, like any other society, has its own social system that has derived a way of living to its members by means of its aspects and elements (relations and social institutions).

- This means of living can be expressed by the concept of "culture" that has two aspects - material- food, costume, house, goods, instruments...; moral- language, value, religion, custom....

- Kurdish social system is a patriarchal society. That's why the patriarchal values are common and affective in them.

- The most common values of Kurdish society are: dignity, manliness, bravery, being older in age, acquaintance... 


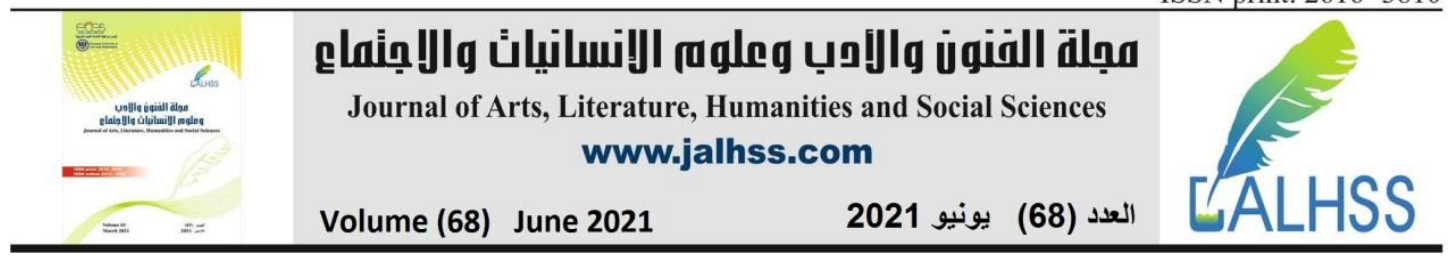

- Kurdish society is at a critical point, that's why apart from the classical values (the ones that are mentioned above) emerges modern values in the system such as; democracy, diverse (nations, politics, religions...) equity, women rights, children rights, social justice...

- At the moment, we can note that new and modern values are gradually re-established within the Kurdish community and are being implemented: democracy, disintegration, women's rights, equality.

\section{References:}

1. Ai- Khassit, Khussa Aurtagha. 2011. Tamrd Al-jamaheer. Translated by Ali Ibrahim Ashqer. Demashq: Dar-Takwen.

2. Al-Buiumi, Muhammad Ahmed. 2002. Almi Achtmae Al-thaqafi. Al-Askandarea: Dir Al-maaref Al-jameea.

3. Al-Jalbi, Ali Abdul Al-Razaq. 1984. Drasat fi Al-muchtamae we Al-thaqafa Alshakhseya. Dar Al-Nahtha Al-Arabeea leltaba .

4. AL-Khteb, Muhammad. 2005. AL-Anthropologya Al-Thaqafya. Demashq.

5. Ember, Carol A., Melvin Ember, and Peter N. Peregrine. 2007. Anthropology . 13. U.S.A.

6. Ghidz, Antoni. 2005. Sociology. Translated by Fayis Al- Sayikh. Bayrut: Tarchaman.

7. Hachman, Rui C. 1989. AL-Lugha we AL-Hayat we AL-Tabeat AL-Bashareya. Translated by Dawed Halmi Ahmed Al- saaed. kwet Universty.

8. Hadsn. 1987. Alem Lugha AL-achdamayi. Edited by Abdul Sallam AL-Aesaam. Translated by Mahmood Aeadd. Baghdada.

9. Jedins, Antoni. 2000. Qaweed Jadeeda lelmanhach fi Alem Al-achtemae. Edited by Muhammad Mahmood Al-chawharri. Translated by Muhammad Mhi Al-deen. AlMachles Ala lelthaqafa.

10. Kimmel, Michael, and Any Aronson. 2008. Sociology Now. U.S.A: pearson.

11. Mir, Lussei. 1983. Maqadima fi Al-Anthropology Al-Achtmaai. Translated by Shakir Mustafa Salim. Bagdaad.

12. Miran, Rashad. 2016. Chand Babateki Ethno Komalaeati. Vols. 1-2. Hawler: Rojhalat.

13. Qanuniyah, Sallah. 2010. Nazarya Al-qeaam fi Alem Al-achtmae. Beruit: Al-tanwer.

14. Salim, Shakir Mustafa. 1981. Qamus Al-Anthropology. kweit.

15. Scott, John, and Gordon Marshal. 2009. Oxford dictionary of sociology. Oxford University Press.

16. Strauss, Klud Levi. 1997. Al-areq we Al-tarekh. 3. Translated by Salem Hadad. Biruet. 